\title{
Beyond Inclusion: Reconsidering Policies, Curriculum, and Pedagogy for Roma Students
}

\author{
Maja Miskovic \\ Concordia University Chicago \\ U. S. A. \\ Svjetlana Curcic \\ University of Mississippi \\ U. S. A.
}

\begin{abstract}
This paper investigates the policies and politics of including European
Roma students in mainstream educational systems within the context of two

European Union (EU) policies: the Decade of Roma Inclusion (2005-2015) and EU

National Roma Integration Strategies (2013-2020). Drawing on the scholarship about

inclusion and its practical achievements, we examine the tensions between policy

planning and policy implementation. We conclude that there is a discrepancy

between what inclusion represents in current educational discourse and how

inclusive efforts are working (or not) for Roma students.
\end{abstract}

KEYWORDS: European Roma students, European Union policy, inclusion,

curriculum for minority, educational policy for minority

Policy Initiatives in the Context of Roma Education in Europe

Frameworks of Inclusion in Education

Tensions between Policies and Practices of Roma Inclusion

Conclusion

Implications

Recommendations

References

Author Contact

Interviewer: Does your daughter go to school?

Mother: $\quad$ She finished elementary school, that special school, and I can't afford to school her further.

Interviewer: Did you go to school?

Mother: Well, I finished only two grades in that special school for mentally unstable children.

Daughter: (chimes in) I completed grade eight in the mentally retarded school.

The above dialogue between a researcher and Roma mother was recorded in Jakšić's (2007) study on education and schooling of Roma children in Serbia. It prefaces what this paper is about: the policies and politics of educating Roma students in European educational systems. 
The largest ethnic minority without a nation state, 10 to 12 million Roma live in Europe, mostly in East European countries (Roma Education Fund [REF], 2013). In this region, a discourse on inclusion runs parallel with the discussion on mental retardation (Greenberg, 2010) and the connotations of the socialist pedagogical discipline of "defectology" linger in the background of cross-cultural curricula and multicultural understanding (Macura Milovanović, Gera, \& Kovačević, 2011). The unintentionally ironic word choice of the "mentally retarded school" expresses aptly the mixed - and often opposing - messages surrounding education in this region.

Roma have been only recently officially recognized as a minority in some countries, but the status of minority has not necessarily improved Roma living conditions or their educational prospects. Therefore, the dilemma central to inclusive policies remains the realization of inclusive education so that "mentally retarded schools" are deemed equally unnecessary for the Roma and ethnic majority population students. This paper addresses inclusion of European Roma students into mainstream educational systems in the context of EU policies. These policies include: (a) the Decade of Roma Inclusion 2005-2015 (the Decade), a European policy that attempted to alleviate and eliminate the effects of discrimination and marginalization of European Roma and (b) The EU National Roma Integration Strategies 2013-2020. Drawing upon the scholarship about inclusion and its practical achievements, we discuss the discrepancy between inclusion as represented in current educational discourse and inclusive efforts that are working (or not) for Roma students.

Our main source of data comes from peer-reviewed studies and research reports commissioned by European governing bodies and non-governmental organizations (NGOs). We did the search in the EBSCO Host database that combined Academic Premier Search and ERIC databases by using the following descriptors: Roma or Gypsies or Traveller or Sinti or Ashkali or Manush or Dom or Lom and "education" or "policy." This search yielded 255 articles in peer-reviewed journals. In reviewing book chapters, European Union (EU) reports, and European NGO reports, we focused on "Roma education" and "educational policy." Finally, we reviewed individual states' Decade Action Plans and reports related to National Strategy Integration 2013-2020 in order to see how educational inclusion is understood and its realization assessed. We read the sources with the purpose of highlighting the intertwined and sometimes opposing developments pertinent to inclusive education in general, and Roma education, in particular.

\section{Policy Initiatives in the Context of Roma Education in Europe}

Numerous research reports have documented widespread marginalization and discrimination of Roma that affect their participation in formal education (e.g., Brüggemann, 2012; European Commission, 2014; Rorke, 2011; Tremlett \& McGarry, 2013; UNICEF, 2011). For example, the importance of access to quality early childhood education and care is recognised, but wide disparities among nation states are present: Pre-school education for Roma children ranges from $0.2 \%$ in Kosovo, to $17 \%$ in Romania (UNICEF, 2011), to $79 \%$ in Hungary (European Commission, 2014). Across South-Eastern Europe, 18\% of Roma attend secondary school, compared with $75 \%$ of the majority population, and less than $1 \%$ of Roma attend 
university (UNICEF, 2011). In spite of numerous court cases across Europe, there is persistent segregation of Roma children in "special schools" and separate classes within mainstream schools. The segregation in mainstream schools attended by Roma is as follows: Slovakia: $58 \%$, Hungary: $45 \%$, Czech Republic: $33 \%$, Bulgaria: 29\%, Romania: $26 \%$. The statistics for Roma children attending special schools mainly with Roma are Czech Republic: 23\%, Slovakia: 20\%, Bulgaria: 18\% (European Commission, 2014).

A number of policy initiatives have been proposed within EU member states and states that aspire to join the EU. One of those policies is the Decade of Roma Inclusion (2005-2015) aimed at eliminating marginalization and discrimination of the Roma minority in four priority areas: housing, health care, employment, and education. Each of the 12 countries that joined the Decade (Albania, Bosnia and Herzegovina, Bulgaria, Croatia, the Czech Republic, Hungary, Macedonia, Montenegro, Romania, Serbia, Slovakia, and Spain) was required to develop a national Action Plan. The Action Plans were to include national assessments and to provide clear and pragmatic goals and transparent benchmarks to demonstrate the progress of Roma students in formal education (Curcic, Miskovic, Plaut, \& Ciobanu, 2014). The implementation of the goals depended on an accountability system that included local municipalities and schools, stakeholders in Roma and non-Roma political and educational organizations, and governments, as well as pan-European bodies such as the European Council. What the Decade did not account for was the intensity of anti-Roma sentiments and the lack of social reforms on a broader societal level. Consequently, the effects of the Decade were haphazard and fragmented. It is likely implausible to achieve educational inclusion without social inclusion. Individual schools and teachers are supposed to perform "heroic acts," while the larger system remains intact. Furthermore, "Roma civil society remains weak in terms of influence and pressure, dependent on EU and foreign aid, opportunistic, and inexperienced in dealing with the complexities of efficiently influencing the Member States and European agendas" (Nicolae, 2015, para. 6).

Despite some progress made in education, mainly through the advancement of literacy and the completion of primary and some secondary schooling (Friedman, 2013), since the end of the Decade there has been little evidence that disparities between Roma and non-Roma citizens of Europe have decreased.

With the Decade's minimal success, the EU proposed another comprehensive and expanded policy: National Roma Integration Strategies 2013-2020 in 28 EU member-states. The EU Framework for National Roma Integration Strategies was adopted in 2011 but each state was left to tailor its national policy according to its own national situation (EU, 2014b). The European Council proposed a multi-year financial framework for 2014-2020 that facilitates the use of EU funds for Roma integration. On a positive note, the importance of early childhood education has been widely recognized across the member states (EU, 2014b). An assessment of the implementation of the new national strategies indicates that a few member states have increased the enrollment rate of Roma children in preschool: for example, Sweden reported an increase from $2 \%$ to $60 \%$ (over a 10 -year period), Hungary to $79 \%$, but there is much to be desired as measures implemented in many states (e.g., Greece) are still insufficient or non-existent. The report, based on a survey from 11 out of 28 member states (Bulgaria, the Czech Republic, France, Greece, Hungary, Italy, Poland, Portugal, Romania, Slovakia, and Spain), noted that in Greece, Romania, Bulgaria, France, and Italy many Roma children of all ages fail to attend 
compulsory schooling (European Union Agency for Fundamental Rights [FRA], 2014). Also, 89\% of Roma surveyed aged 18-24 had not acquired upper secondary education. Without efforts to enable young Roma to become young professionals, the prospects for Roma inclusion remain slim.

\section{Frameworks of Inclusion in Education}

Inclusion as a concept has established a ubiquitous presence in the world of education and educational policies. However, definitions of inclusion are "all over the place, representing diverse perspectives and ideologies" (Smith, 2010, p. 38), causing confusion as to what it implies (Ainscow, 2007), or are used to describe practices that are not inclusive at all (Giangreco, 1997). The past decade marks a critical examination of the term, practice, and movement of inclusion. The term itself carries epistemological, ideological, and political implications and positioning (Smith, 2010; Ware, 2004).

We are reluctant to offer a singular definition of inclusion as we concur with Slee (2013) who argues that "defining inclusion might be a distraction" and that the real challenge for us was to "learn how to detect, understand, and dismantle exclusion as it presents itself in education. This is particularly important when it is apparent that much of the activity advanced in the name of inclusive education has exclusionary effects" (p. 905). Roma students are still disproportionally placed in special education or segregated classes. Even when schools commit to inclusion, their efforts are often limited to considerations of how to integrate students with special education needs into mainstream classrooms (Booth, 2011). Certainly, the philosophy and practice of inclusion are not synonymous with special education (Ainscow \& César, 2006; Giangreco, 1997). The practices meant to support inclusion refer not only to students with special needs, but also to various groups of students with cultural and linguistic differences. Cultural and linguistic differences often lead to segregated education (Harry, 2005). As Acton (1998) argues, however, "The perception of ethnicity as disability remains subliminally damaging, especially for Gypsies where the achievement of an antiracist approach remains fragile" (p. 15).

To reframe inclusion from the question of student placement (e.g., percentage of time spent in regular classrooms), several researchers go beyond the placement and focus on curriculum. For example, Hooley and Levinson (2013) propose a discursive environment for teaching and learning that challenges a predetermined curriculum of formal schooling and is open to teacher and student action and intellectual risks. The authors question the capacity of education systems founded on colonial and nation state ideologies to serve all segments of a community. Some progress has been made as several native and indigenous people (e.g., in Alaska, Canada, and New Zealand) have asserted their right to a more culturally adaptive form of schooling. Yet, in many countries, the ways of knowing are still disconnected from the community perspectives and students who are not equipped with the "right" cultural capital.

Depending on the disciplinary/theoretical anchor such as disability, race/ethnicity, or queer studies and prospective identity markers, the discourse on inclusion usually refers to separate groups of students. Against the framework of separately discussing various groups of students who are often educationally 
marginalized and socially excluded, Booth (2011) argues for a "principled approach to the education and society [emphasis in original] through a framework of inclusive values" (p. 304).

Schools should not simply mirror the society but also should aim to recreate society by producing citizens with a new vision (Curcic, Gabel, Zeitlin, CribaroDiFatta, \& Glarner, 2011). Yet, there seem to be numerous barriers to achieving the goal of changing societal values through education alone. For example, headlines in daily papers across various European countries consistently portray Roma as the "Other." Also politicians, such as a few mayors (e.g., Croatia and Italy) and prime ministers (e.g., Slovakia), and especially the members and followers of radical nationalist parties (e.g., Yobbik in Hungary), often engage in "othering" Roma, regardless of whether Roma represent their long-time citizens or immigrants. Warning of a new wave of anti-Roma sentiment, Rudo Kawczynski (cited in Ettienne, 2012), the president of the European Roma and Travellers Forum, noted that the Roma are both scorned (for their ethnic/cultural heritage) and cursed because they dare to leave the countries in which they face prejudice. Our analysis reveals numerous tensions in inclusive education, in general, and Roma education, in particular. We discuss some of those tensions as a way of establishing points to be considered when creating educational policies and practices alike.

\section{Tensions between Policies and Practices of Roma Inclusion}

Various tensions exist between policies and practices that intend to include Roma students in educational settings. Three tensions are highlighted here: (a) between inclusive education as a technical pursuit rather than evolving ethical acts; (b) between policy planning vs. policy implementation; and (c) between making schools ready for students and students ready for schools.

\section{Inclusive Education as a Technical Pursuit vs. Evolving Ethical Acts}

Teachers are often seen as "key institutional agents of change" and as "politically aware and culturally informed citizens to assure social justice to a historically marginalised ethnic minority" (Bereményi, 2011, p. 355). Nonetheless, in Serbia, for example, the teacher education curriculum addresses inclusion in a single subject. The approach still reflects the tenets of defectology and the discourse is medical, without attention to social justice or broader political and cultural circumstances that shape the discourse of inclusion (Macura Milovanović et al., 2011). Addressing indigenous education, Hooley and Levinson (2103) argue that governments and education systems "have major epistemological and pedagogical problems in implementing reforms in the interest of disenfranchised peoples, let alone in transforming the curriculum and teaching in mainstream schools" (p. 143). In addition, Winch (2012) argues that the current official idea of teaching pushes aside conceptual and foundational thinking and reflects teaching as a mostly technical pursuit. How-to approaches to curriculum have replaced critical thinking or assigned it to isolated pockets. 
Technical and managerial approaches to education lock teachers and parents into isolation and unequal power relations far removed from what Noddings (2010) calls "relational ethics of care" (p. 391). A managerial approach to education is in contrast to Booth's (2011) vision of school as a place "responsive to diversity in ways that value equally all children, young people and their families and the adults who work with them (p. 304, emphasis in original). Despite research that refutes the stereotype of Roma parents who simply "don't care" about their children's education (Srdić, 2010; Srdić \& Sučević, 2012), this wrongly held common perception has not changed.

Student-teachers also believe that Roma parents and students are the main causes of the academic underachievement of Roma students, while the causes of this underachievement related to teachers and schools are minimized (Macura Milovanović \& Peček, 2013). The education of future and current teachers is embedded in a society where public discourse abounds with open hatred toward the Roma. In Serbia, for instance, it is common that magazines publish racist jokes with Roma characters or that the newspaper titles read "New Homes for the Gypsies, While the Serbs, Earthquake Victims Are Still Waiting" (Tanjug, 2013) or "Let's Plan to Get Rid of the Mangy Gypsy Criminals" (Necim, 2013). Such rhetoric does not represent a few isolated incidents in a single country. Monitoring reports on the Decade policy reveal that discrimination against Roma is on the rise in Bulgaria, the Czech Republic, and Hungary (The Decade of Roma Inclusion Secretariat Foundation, [Secretariat], 2013). The 2014 report by the François-Xavier Bagnoud Center for Health and Human Rights (FXB Center) at Harvard University warns of a climate of increasing social and economic exclusion in Hungary, created by vigilante groups and hate crimes against minorities, especially Roma. In addition to hate crimes and violence toward Roma, especially disturbing is the use of racist public statements by state officials and members of mainstream parties that "incite hate against Roma and other minorities" (FXB Center, 2014, p. 8).

\section{Policy Planning vs. Policy Implementation}

The analysis of the Decade, in which the governments of 12 countries developed national Action Plans to help eliminate marginalization and discrimination of the Roma minority, provides little evidence that disparities between the Roma and non-Roma population of Europe have decreased (Secretariat, 2013). The Action Plans were problematic in both the way they were formulated and the way they were going to be implemented and monitored (Curcic et al., 2014). For example, the educational goals for Roma youth as stated in the Action Plan of the Decade in Montenegro proposed vocational training adjusted to the Roma population to include "metal processing crafts, metal masterpiece production, raw material processing, wooden masterpiece production, musical instruments production, etc." (as cited in Curcic et al., 2014, p. 12). Thus, the education of Roma youth might get them ready for low paying and vanishing professions. Also, most Action Plans lacked baseline data, which made progress monitoring impossible.

Recognizing that the implementation of the Decade was inconsistent in many fields, the EU member states replaced the Decade policy with a new National Roma Integration Strategy 2013-2020 (based on the new EU Framework for Roma 
Integration Strategies up to 2020). The EU Framework established a multi-year Financial Framework for 2014-2020 allocating at least $20 \%$ in each member state to combating poverty and social exclusion. The EU Commission set 28 National Roma Contact points (in $28 \mathrm{EU}$ member-states) to support coordination and implementation of the strategies and to exchange and share experiences between member states, international organizations, and NGOs. In the educational arena, some initiatives have been recognized as positive actions. For example, several states made preschool a part of compulsory education (e.g., Finland and Hungary). This is an important practice in view of the FRA (2012) report, which indicates that a late start seems to be the major reason for not attending compulsory school. Romania introduced dedicated places for Roma to be admitted to public universities (e.g., in 2012/13, 564 places were designated for Roma admission). However, the learning gaps and dropout rates after compulsory schooling are still a concern, together with the persistence of segregation of Roma children in special schools or classes in several member states (e.g., the Czech Republic and Slovakia).

The European institutions are setting forward educational evidence-based practices that "have demonstrated their effectiveness through rigorous research" (EU, 2014a). Evidence-based research and practices, however, understand "evidence" in an overly technical and narrow way and do not take into account the complexities of working with disenfranchised individuals and communities (Tremlett \& McGarry, 2013). This is coupled with the general lack of political will on the part of the governments to address the weak or nonexistent infrastructure that leaves many of the proposed policy goals unfulfilled (Rorke, 2011).

\section{Making Schools Ready for Students vs. Students Ready for Schools}

Many schools use norm-referenced tests to evaluate children's readiness for school. Norm-referenced tests are largely under-normed on Roma populations, but are nonetheless used in the Czech Republic, Hungary, Serbia, and Slovakia (White, 2012). White makes several recommendations based on her analysis of preschool assessment of Roma children across these four countries, such as (a) providing universal access to inclusive preschool education; (b) using assessment to inform instruction rather than for the purposes of streaming children towards special education; (c) focusing on making schools ready for children rather than children for the school, along with restructuring teacher education programs and their professional development; and (d) informing parents about the diminished long-term educational and employment prospects for children entering special education. Because education correlates with labor prospect outcomes, the last point seems especially important in view of the cumulative effects of discriminatory streaming of Roma into special remedial schools (O'Higgins \& Brüggemann, 2014).

In 2007 the European Courts of Human Rights (ECHR) condemned discrimination against Roma children resulting from their placement in special schools, segregated schools, or Roma-only classrooms in Croatia, Greece, and the Czech Republic (Memedov, 2010). Upon inspection in 2010, the situation was deemed unchanged in all three countries. However, several principals asked that free programs be introduced for Roma children before the start of their elementary schooling in the region of Medjimurje in Croatia. It took several years to organize free 
preschool for Roma children, but it is now considered one of the best investments for young Roma (personal communication with the Medjimurje Region representative B. Susec, 2016). Schools in this region employed Roma assistants. The assistants help Roma children and mediate between the school and the community. Workshops for parents are also regularly organized, attended jointly by Roma and Croatian parents.

In a study of ethnic differences and prospects for urban youth in an enlarged Europe, Szalai (2011) noted that the majority of Roma parents and students were dedicated to an education that goes beyond elementary schooling. However, Roma youths' dreams and aspirations were limited by an "ethnic ceiling." They considered future vocations where experience has shown that Roma presence is tolerated, such as in construction work, traditional industry, hairdressing, or cobbling (Szalai, 2011, p. 21). Yet, a case study of 18 Roma youth in Romania by Nistor, Stanciu, Vanea, Sasu, and Dragotă (2014) portrays youth inspired to develop interests in various fields (e.g., medicine, language, dance, etc.) with support of their parents or teachers. In other words, Roma students need teachers who will dream with them as opposed to "protecting" them from future disappointments (Szalai, 2011, p. 22).

Understanding public schooling as an a priori integrated, highly desirable space for Roma students has been questioned in recent research (e.g., Derrington, 2010; Hemelsoet, 2011; Miskovic, 2013). Certainly, segregated schooling based on racism and poverty must end (Merry, 2012; New, 2012), but the "agenda of multicultural education seems not to recognize that integrated schooling per se may just bring the victims of stigmatization closer to unsympathetic majority group of teachers and students" (New, p. 58). Considerations with a specific focus on Roma education could include specialized colleges such as those colleges for Roma youth that successfully operate in Hungary. These colleges strengthen Roma cultural identity and foster their integration in the broader society. Roma colleges nurture Roma intellectual elite who could bridge the grass-root and academic discourses and take an active part in the realization of social policies for and by Roma (Forray, 2013). As New (2012) observed, the focus on supporting Roma-centric institutions could be increased as opposed to focus on integration "at all costs" (p. 23). This approach away from inclusion short-term, but laying a foundation for Roma inclusion long-term, might be an approach that could be further explored across the EU member states.

Roma students also benefit from initiatives such as those of the Roma Education Fund that provides scholarships for higher education for Roma youth and supports communication among beneficiaries of the program. The Roma Education Fund also provides financial support for small-scale projects for Roma community development (Garaz, 2014).

\section{Conclusion}

The examination of inclusive policies and practices across a number of European states reveals the intertwined and sometimes opposing developments pertinent to inclusive education. Both overt and covert racist behaviors make school environments hostile to many Roma students. There are tensions that seem to be inherent in inclusion within the schools that are not ready for all students but expect all students to be ready for inadequately prepared schools. Practices that sort out 
Roma children based on their "readiness" for the school begin as early as preschool and continue throughout elementary and secondary schooling. Those Roma students who continue their schooling and develop interests and aspirations toward various career goals often face an "ethnic ceiling" and lower their aspirations based on the normative societal or teachers' expectations. However, Roma youth cannot wait for schools to be ready for them. They need solutions to prejudices and animosity that over time, especially in times of economic recessions, seem to have increased, not decreased.

Several researchers (e.g., Booth, 2011; Hooley \& Levinson, 2013; Nicolae, 2012) propose a curriculum and pedagogy that aim to establish respectful and inclusive approaches to knowing. Yet, a monocultural curriculum seems to persist across various EU countries. The curriculum, coupled with EU/international exams and assessments in education (e.g., PISA), is likely to undermine awareness of the need for revamping both the curriculum and pedagogy to better meet the needs of those who enter schools with cultural capital that is not aligned with "mainstream" expectations. Consequently, radical redesigns of both curriculum and pedagogy are in need of a much more concerted effort on the part of researchers, educators, and policy makers.

\section{Implications}

One of the major problems that Roma face is discrimination that starts in the schools, continues into their adulthood, and affects their labor prospects. While there is no lack of legislative regulations, there are still problems in their implementation. Slovakia, for example, instituted an amendment to the Anti-discrimination Act that introduces temporary measures that may be adopted on the grounds of ethnicity in education, employment, health care, social security, and access to goods and services. Roma people have been living in Europe since the $14^{\text {th }}$ century but were only recently recognized in official government documents as an ethnic minority. The Czech Republic announced an amendment of Decree on education forbidding placement of socially disadvantaged children into educational programs for disabled students (European Commission, 2014). However, as the EU report on the Implementation of the EU Framework for National Roma Integration Strategies 20132020 suggests, the member-states should not rely on stand-alone policies or amendments (EU, 2014b). One of the implications is that fighting discrimination should be embedded into all state policies. Unfortunately, discriminatory discourse seems to be on the rise with the recent increase in the number of refugees from the Middle East in various EU states. Consequently, the implication for every single state in the EU and beyond is that inflammatory racist rhetoric needs to be immediately recognized as such and not tolerated.

Although the focus of our analysis was on education, it needs to be recognized that some Roma children are educated in living conditions in which they lack electricity, even water. The EU structural funds are therefore important. However, in the 2007-2013 period, the EU funds for "disadvantaged people" were not fully used for various reasons, predominantly administrative, and due to poor cooperation between state authorities and Roma. This is why in 2014-2020 an integrated approach to funding in various domains will focus on cooperating with the 
most disadvantaged micro-regions, not only state governments. Such an approach, termed "territorial," has already resulted in improvements in living conditions and education in the Medjimurje region of Croatia. Nonetheless, there are still gaps identified in desegregation measures at all levels of education and measures to reduce leaving school early. More detailed timeframes of implementation are also needed across the EU member states. The implication for implementing policies in practice is that communicating positive experiences among the EU member states is probably one of the best points of the new National Roma Integration Strategies 2013-2020 that established 28 points of communication across the member states.

\section{Recommendations}

Many assessments of the implementation of Roma inclusion in education still note that desegregation measures are yet to be enforced (EU, 2014b). Monitoring the implementation of educational policies at the school level is important, but insufficient. Closer cooperation with Roma families is needed. Bringing Roma and other families together in workshops, as implemented in the one Croatian region noted earlier, seems to diminish the "otherness" feelings and conceptions. We recommend that states with large Roma populations living in proximity to majority populations make an effort to bring parents together. Because early childhood education has been recognized as crucial for Roma inclusion in the educational system, we recommend that the governments of various states make sure that administrative measures (e.g., identity cards and similar issues) do not present obstacles but instead provide an opportunity to collaborate with Roma parents.

It is possible that a targeted focus on Roma students (e.g., specialized colleges) might create better educational opportunities for Roma youth than inclusion into all universities. Support for Roma students in higher education, such as the one provided by the Roma Education Fund, is one of the most recent efforts towards supporting Roma students in completing higher education studies (Garaz, 2014). Rather than contemplating whether such initiatives present inclusion or exclusion, we recommend that each state consider not only the admission of Roma students (as is the case in Romania that allocated spaces for Roma students), but also consider measures of support to help ensure success once the Roma students are admitted.

Education is intertwined with the existing living conditions of Roma. It is therefore important to combine both education planning and living infrastructure improvements for Roma. The infrastructure pertains to legalizing Roma settlements so that further improvements can be made in electricity and water supplies. Such projects are costly. We recommend that the governments of the EU states learn how to better access the EU funds, as it has been noted that not all of the funds were used due to various administrative barriers. Similarly, Roma NGOs need to learn how to take advantage of possibilities offered through the Roma Education Fund for smaller scale projects related to Roma community developments. 


\section{References}

Acton, T. (1998). Authenticity, expertise, scholarship and politics: Conflicting goals in Romani studies. University of Greenwich Inaugural Lecture Series. Retrieved from http://www.gypsy-traveller.org/pdfs/acton_article.pdf

Ainscow, M. (2007). Taking an inclusive turn. Journal of Research in Special Educational Needs, 7(1), 3-7.

Ainscow, M., \& César, M. (2006). Inclusive education ten years after Salamanca: Setting the agenda. European Journal of Psychology of Education, 21(3), 231-238.

Bereményi, B. A. (2011). Intercultural policies and the contradictory views of teachers: The Roma in Catalonian schools. Intercultural Education, 22(5), 355-369.

Booth, T. (2011). The name of the rose: Inclusive values into action in teacher education. Prospects, 41, 303-318.

Brüggemann, C. (2012). Roma education in comparative perspective. Analysis of UNDP/World Bank/EC regional Roma survey 2011. Roma inclusion working papers. Bratislava, SL: United Nations Development Programme.

Curcic, S., Miskovic, M., Plaut, S., \& Ceobanu. C. (2014). Inclusion, integration or perpetual exclusion? A critical examination of the Decade of Roma Inclusion, 2005-2015. European Educational Research Journal, 13(3), 257-267.

Curcic, S., Gabel, S. L., Zeitlin, V., Cribaro-DiFatta, S., \& Glarner, C. (2011). Policy and challenges of building schools as inclusive communities. International Journal of Inclusive Education 15(1), 117-133.

Derrington, C. (2010). "They say the grass is blue": Gypsies, travellers and cultural dissonance. In Rose, R. (Ed.). Confronting obstacles to inclusion: International responses to developing inclusive schools (pp. 31-43). London, UK: Routledge.

Ettienne, T. (2012). Europe still struggles to get to grips with Roma community. Generation112.eu. Retrieved from http://en.generation112.eu/Europe-stillstruggles-to-get-to-grips-with-Roma-community_a241.html

European Commission. (2014). The European Union and Roma - Factsheet Czech Republic. Retrieved from http://ec.europa.eu/justice/discrimination/files/ roma_country_factsheets_2014/czech-republic_en.pdf

European Union. (2014a). European platform for investing in children. Retrieved from http://europa.eu/epic/practices-that-work/evidencebasedpractices/ index_en.html

European Union. (2014b). Report on the implementation of the EU framework for national Roma integration strategies. European Commission-DirectorateGeneral for Justice. Retrieved from http://ec.europa.eu/justice/discrimination/ files/roma_implement_strategies2014_en.pdf 
European Union Agency for Fundamental Rights (FRA). (2014). Education: The situations of Roma in 11 EU member states. Luxembourg, LU: Publications Office of the European Union.

Forray, K. R. (2013). Colleges for Roma in higher education. Hungarian Educational Research Journal, 3. Retrieved from http://herj.lib.unideb.hu/index.php? oldal=archivum\&folyoirat_szam $=3 / 2013$

Friedman, E. (2013). Decade of Roma inclusion progress report. UNDP. Retrieved from 20REPORT.pdf http://www.eurasia.undp.org/content/dam/rbec/docs/DORI\%

FXB Center for Health and Human Rights. (2014). Accelerating patterns of antiRoma violence in Hungary. Boston: Harvard University. Retrieved from http://fxb.harvard.edu/wp-content/uploads/sites/5/2014/02/FXB-HungaryReport_Released-February-4-2014.pdf

Garaz, S. (2014). Helping the marginalised or supporting the elite? Affirmative action as a tool for increasing access to higher education for ethnic Roma. European Educational Research Journal, 13(3), 295-311.

Giangreco, M. F. (1997). Key lessons learned about inclusive education: Summary of the 1996 Schonell Memorial Lecture. International Journal of Disability, Development and Education, 44(3), 193-206.

Greenberg, J. (2010). Report on Roma education today: From slavery to segregation and beyond. Columbia Law Review, 110(4), 919-1001.

Harry, B. (2005). Equity, excellence and diversity in a rural secondary school in Spain: 'Integration is very nice, but...'. European Journal of Special Needs Education, 20(1), 89-106.

Hemelsoet, E. (2011). Questioning the homogenization of irregular migrants in educational policy: From (il)legal residence to inclusive education. Educational Theory, 61(6), 659-669.

Hooley, N., \& Levinson, M. (2013). Investigating networks of culture and knowledge: A critical discourse between UK Roma Gypsies, indigenous Australians and education. Australian Education Research, 41, 139-153.

Jakšić, Lj. (2007). Education and schooling of Roma children. Društvene nauke o Romima u Srbiji, Srpska Akademija Nauka i Umetnosti [Social Sciences on Roma in Serbia, The Serbian Academy of Science and Arts], Beograd, 81-93. [in Serbian]

Macura Milovanović, S., Gera, I., \& Kovačević, M. (2011). Preparing pre-service teachers for inclusive education in Serbia: Current situation and needs. Zbornik Instituta za Pedagoška Istraživanja [The Journal of the Pedagogical Research Institute], 43(2), 208-222.

Macura Milovanović, S., \& Peček, M. (2013). Attitudes of Serbian and Slovenian student teachers towards causes of learning underachievement amongst Roma pupils. International Journal of Inclusive Education, 17(6), 629-645.

Memedov, I. (2010). Roma rights: Implementation of judgments. Retrieved from http://www.errc.org/article/roma-rights-1-2010-implementation-ofjudgments/3613/10 
Merry, M. (2012). Segregation and civic virtue. Educational Theory, 62(4), 465-486.

Miskovic, M. (2013). European Roma and inclusive education: Notes on promises and shortcomings. Hungarian Educational Research Journal, 3. Retrieved from

http://herj.lib.unideb.hu/index.php?oldal=archivum\&folyoirat_szam=3/2013

Necim, G. (December 23, 2013). Planski da se resimo sugavih Cigana kriminalaca [Let's plan to get rid of the mangy Gypsy criminals]. Retrieved from http://www.e-novine.com/srbija/vesti/96314-Planski-reimo-ugavih-Ciganakriminalaca.html

New, W. (2012). Stigma and Roma education policy reform in Slovakia. European Education, 43(4), 45-61.

Nicolae, V. (2012). Too little, too cheap. Retrieved from http://theeuropeanmagazine.com/533-nicolae-valeriu/534-european-roma-policies

Nicolae, V. (2015). No accountability - the case of the Roma social inclusion in Europe. Open Democracy. Retrieved from https://www.opendemocracy.net/ can-europe-make-it/valeriu-nicolae/nonaccountability-\%E2\%80\%93-case-ofroma-social-inclusion-in-europe

Nistor, N., Stanciu, D., Vanea, C. Sasu, V. M., \& Dragotă, M. (2014). Situated learning in young Romanian Roma successful learning biographies. European Educational Research Journal, 13(3), 312-324.

Noddings, N. (2010). Moral education in an age of globalization. Educational Philosophy and Theory, 42(4), 390-396.

O'Higgins, N., \& Brüggemann, C. (2014). The consequences of cumulative discrimination: How special schooling influences employment and wages of Roma in the Czech Republic. European Educational Research Journal, 13(3), 282-294.

Roma Education Fund (2013). Retrieved from http://www.romaeducationfund.hu/

Rorke, B. (2011). Beyond rhetoric: Roma integration roadmap for 2020. Open Society Institute. Retrieved from http://www.opensocietyfoundations.org/sites/ default/files/beyond-rhetoric-2011-0616.pdf

Slee, R. (2013). How do we make inclusive education happen when exclusion is a political predisposition? International Journal of Inclusive Education, 17(8), 895-907.

Smith, P. (2010). Defining inclusion: What is it? Who does it benefit? In Smith, P. (Ed.). Whatever happened to inclusion? The place of students with intellectual disabilities in education (pp. 38-60). New York, NY: Peter Lang.

Srdić, V. (2010). Inkluzivno obrazovanje u mikrosistemu: Saradnja predskolske ustanove i romske porodice. [Inclusive education in a micro-system: Cooperation of the preschool institution and Roma families]. Pedagogija, 65(1), 18-25.

Srdić, V., \& Sučević, V. (2012). Empirijska provera razloga nedovoljne ukljucenosti romske dece u predskolske ustanove u Srbiji [The empirical verification of the reasons for the insufficient inclusion of Roma children into preschool institutions in Serbia]. Teme, 36(3), 1397-1419. 
Szalai, J. (2011). Ethnic differences in education and diverging prospects for urban youth in an enlarged Europe. Budapest, HU: EDUMIGROM, Center for Policy Studies, Central European University.

Tanjug (December 22, 2013). U Kraljevu grade stanove za Cigane, a pitanje beskucnika Srba jos nije reseno [New homes for the Gypsies, while the Serbs, earthquake victims are still waiting]. Retrieved from http://www. vaseljenska.com/vesti-dana/u-kraljevu-grade-stanove-za-cigane-pitanjebeskucnika-srba-nakon-zemljotresa-jos-nije-reseno/

The Decade of Roma Inclusion Secretariat Foundation (Secretariat). (2013). Decade of Roma Inclusion 2005 - 2015. Retrieved from http://www.romadecade.org

Tremlett, A., \& McGarry, A. (2013). Challenges facing researchers on Roma minorities in contemporary Europe. ECMI Working Paper \#62. Retrieved from http://www.ecmi.de/uploads/tx_Ifpubdb/Working_Paper_62_Final.pdf

UNICEF (2011). The right of Roma children to education. Retrieved from http://www.unicef.org/ceecis/UNICEF_ROE_Roma_Position_Paper_Web.pdf

Ware, L. (Ed.) (2004). Ideology and the politics of (in)exclusion. New York, NY: Peter Lang.

White, J. (2012). Pitfalls and bias: Entry testing and the overrepresentation of Romani children in special education. Retrieved from http://www.romaeducation fund.hu/sites/default/files/publications/pitfalls-andbias-screen_singlepages.pdf

Winch, C. (2012). For philosophy of education in teacher education. Oxford Review of Education, 38(3), 305-322.

\section{Author Contact}

Maja Miskovic: maja.miskovic@cuchicago.edu

Concordia University-Chicago, 7400 Augusta St, River Forest, Illinois, 60305, USA

Svjetlana Curcic: scurcic@olemiss.edu

University of Mississippi, P.O. Box 1848, University, Mississippi, 38677, USA 